\title{
ANALISES DE LIVROS
}

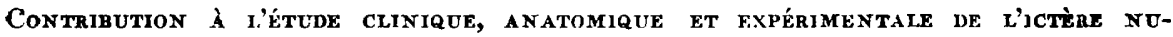
crefaire du nouveau-Né. A. Dereymakker. Um volume com 187 páginas e 32 figuras. Masson \& Cie., Edit., Paris e Editions Arscia, Bruxelas, 1949.

Este trabalho, realizado no Laboratório de Neuropatologia da Universidade Católica de Louvain, é dedicado a uma entidade nosológica cujo conhecimento vem-se desenvolvendo ràpidamente, a partir dos últimos 10 anos. Sua etiopatogenia era completamente obscura até 1940-1941, de quando datam a descoberta do fator $R$ h (Landsteiner e Wiener) e a do fator etiológico da isoimunização nas eritroblastoses (Levine, Katzin e Burham).

Baseado em 31 observações anátomo-clínicas pessoais (12 de icterícia grave familial com síndrome nervosa clínica, 8 de icterícia grave familial sem síndrome nervosa clínica, 1 de provável icterícia infecciosa do recém-nascido, 2 de anemia grave do recém-nascido, 2 de anasarca feto-placentária e 6 de seqüelas de icterícia nuclear), Dereymaeker empreendeu exaustivo estudo da entidade, encarando seas aspectos clínicos, anátomo-patológicos e fisiopatológicos. No estudo do diagnóstico diferencial, o autor chama a atenção para a possibilidade da aproximação de certas síndromes neurológicas infantis, como o status marmoratus e o estado desmielinizante do striatum, do casal Vogt, com as seqüelas de kernicterus; pelo contrário, com as inoléstias de Wilson e de Hallervorden-Spatz, nenhum fato autoriza essa aproximação.

As maiores incógnitas da icterícia nuclear residem em sua fisiopatologia e foi justamente nesse setor que Dereymaker trouxe importante colaboração, baseada em experiências em animais. Pela reprodução da icterícia nuclear no cão (técnica de Eyquem) evidenciou-se experimentalmente o papel etiológico da isoimunizaçăo no desencadear dos quadros clínicos e anátomo-patológicos correspondentes. De fato, na icterícia grave familial, nenhum fator conhecido, a não ser uma reação isoimunológica, pode explicar o aparecimento de lesões nervosas centrais. A prematuridade e o aparecimento de uma eventual disfunção hepática podem agir como fatôres agravantes. Baseado em experiências em cobaias, Dereymaeker verificou que os anticorpos são capazes de alterar a barreira hemoencefálica das crianças e, penetrando no sistma nervoso central, franquear passagem para outras substâncias, tais como a bilirrubina. Interessante assinalar, no entanto, a falta completa de paralelismo entre o grau de pigmentação do neuraxe e a gravidade das lesões histológicas; estas últimas podem existir mesmo na ausência de qualquer pigmentação. Admite o autor que o efeito neurotóxico deriva da reação local antígeno-anticorpo.

$O$ esquema do desenvolvimento do quadro mórbido pode ser assim resumido: pai $R h+$, mãe $R h-$, produção de anticorpos pelo organismo materno (anti-Rh), passagem dêsses anticorpos através da placenta no decurso da gravidez; por uma razão desconhecida, apenas após o nascimento os anticorpos fraqueam a barreira hemoencefálica da criança e determinam as lesões características do sistema nervoso (sobretudo dos núcleos estriados, assoalho do IV ventrículo, olivas bulbares e núcleos denteados do cerebelo), pela reação, nesse nível, antígeno-anticorpo. Baseado nesse mecanismo fisiopatológico, o autor estuda, teòricamente, as possíveis medidas de ação contra cada elo dessa cadêia. Evidentemente, é impossível a redução da produção de anticorpos maternos, bem como a elevação da permeabilidade placentária. A interrupção da gravidez após a viabilidade do feto, foi completamente ineficaz, nos casos tentados; por outro lado, na prática é impossível reforçar a barreira hemoencefálica infantil. Resta apenas o recurso da eliminação dos anticorpos do organismo da criança, por meio da exsangüino-transfusão, tão completa quão necessária. Para 
êsse processo, deve-se usar, segundo alguns autores, sangue $\mathrm{RH}-\mathrm{e}$, segundo outros, sangue $R h+$, preferencialmente do pai, que irá fixar e neutralizar os anticorpos ainda subsistentes. Evidentemente, o sangue materno, rico em anticorpos, fica completamente contra-indicado.

R. Metaragio Fitho 